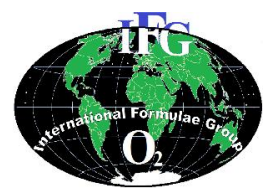

Available online at http://www.ifgdg.org

Int. J. Biol. Chem. Sci. 11(2): 623-639, April 2017

International Journal

of Biological and

Chemical Sciences

ISSN 1997-342X (Online), ISSN 1991-8631 (Print)

Original Paper http://ajol.info/index.php/ijbcs http://indexmedicus.afro.who.int

\title{
Weeds control through tree-crop associations in a parkland of Burkina Faso
}

\author{
Josias SANOU ${ }^{*}$, Hugues Roméo BAZIE ${ }^{2}$, Madjelia Cangré Ebou DAO ${ }^{1}$ and \\ Jules BAYALA ${ }^{3}$ \\ 'Institut de l'Environnement et de Recherches Agricoles (IN.E.R.A); \\ Département d'Environnement et Forêts, 03 BP 7047 Ouagadougou 03, Burkina Faso. \\ ${ }^{2}$ Université de Ouagadougou, Unité de Formation et Recherche en Sciences de la Vie et de la Terre; \\ 03 BP 7021 Ouagadougou 03, Burkina Faso. \\ ${ }^{3}$ World Agroforestry Centre (ICRAF), ICRAF-WCA, Sahel Node, BPE5118 Bamako, Mali. \\ *Corresponding author; E-mail: josiassanou@yahoo.fr; Tel (226) 503340 98, Fax: (226) 50315003.
}

\section{ACKNOWLEDGEMENTS}

This study was funded by the project SAFRUIT/INCO Contract Number 015465 of the European Commission.

\section{ABSTRACT}

The effects of microclimate due to tree presence on weeds development were assessed under Baobab (Adansonia digitata) and Néré (Parkia biglobosa) in a parkland in Nobéré (Burkina Faso). In association with these trees, two crops were grown: a shade tolerant crop (Colocasia esculenta, taro) and a shade intolerant cereal (Pennisetum glaucum, Millet). Weeds species and biomass production were assessed in a plot $(0.5 \mathrm{~m} \mathrm{X}$ $0.5 \mathrm{~m}$ ) in three concentric zones around tree trunk (A, B and C) and in the open field (H). Shannon's diversity index was calculated for each zone of both tree species and both crops. Seventy-six (76) weeds species from nineteen (19) families were recorded on the parkland from which only 13 families were found in the open field. Then, weeds floristic composition was more diversified in area beneath both trees species compared to the open field. The most represented weeds family in the open field was Poaceae while under both tree species, the most recorded species were from Amaranthaceae family. In addition, more weeds species were associated with Néré tree (58 species) compared with baobab tree ( 48 species). The number of weeds species increased from Néré tree trunk (17) to the surrounding area of the edge of tree crown (25) in contrast of baobab tree associated with taro (16 and 6, beneath trunk and crown edge, respectively). Moreover, growing taro under tree crown reduced the number of weeds species and also weeds development (low biomass production) under tree crown compared with millet. Therefore, introducing a shade tolerant crop as taro in parkland agroforestry system could help farmers to control weeds under trees in their farms.

(C) 2017 International Formulae Group. All rights reserved.

Keywords: Adansonia digitata, Colocasia esculenta, Parkia biglobosa, Parkland agroforestry system, Pennisetum glaucum, weeds floristic composition. 


\section{INTRODUCTION}

Parkland agroforestry systems are the practices of growing crops and these scattered trees together on the same area and at the same time (Bayala et al., 2014). These systems are common in West Africa and have been used since ancient times by farmers to obtain both products from trees and crops in order to enhance their food security (Bayala et al., 2014; Yaméogo et al., 2013; Larwanou et al. 2010). Both trees and crops interact underground and above-ground in parkland agroforestry systems (Bayala et al., 2002).

Several workers reported changes in climate parameters under trees compared with the conditions in the open field (Bayala et al., 2002; Noordwijk et al., 2004). The microclimate due to tree presence is characterised by lower sun radiation reaching the soil, lower air and soil temperature, higher air and soil moisture compared with the open field (Bayala et al., 2015). According to these last authors, the reduction of sunlight under tree crown which depends on tree architecture results in a decrease of temperature that finally reduce evaporation under tree crown.

The microclimate created under tree crowns is reported to have various impacts on understored grasses (Kambatuku et al., 2011). The effect of Faidherbia albida tree shade is associated with lower weeds diversity and a significantly lower density of the plant parasite Striga hermontica compared with open areas. Gworgwor (2007) found none emergence of $S$. hermontica under $F$. albida trees whereas the parasite was causing up to $17.13 \%$ reduction of millet panicle yield in open area in Nigeria. Indeed, the lack of radiation under trees selectively suppresses plants which have high demand for light for their development. Ludwig et al. (2004) found a completely different composition of the herbaceous species under Acacia trees compared to open grassland. These authors suggested that the observed different in herbaceous composition was mainly due to nutrient availability because similar species compositions were found for stands with same oil nutrient concentrations while light and water availability were different.

Many workers have also reported a higher biomass production of grasses underneath of trees compared with open areas (Moustakas et al., 2013; Kambatuku et al., 2011). Moustakas et al. (2013) reported that grass biomass production was higher under savanna trees compared to the outside when annual average rainfall was lower than 550 $\mathrm{mn}$ but no different was noticed when annual average rainfall was equal to $737 \mathrm{mn}$. The higher biomass production of plants undernath of tree compared to the outside is explained by more nutrients and water availability under tree (Bayala et al., 2014; Ndiaye Samba et al., 2012; Ludwig et al., 2004).

In sum, trees in parklands agroforestry systems seem to increase weeds problem which is known as the most pest in West African savannah agriculture. Indeed, the major cereal crops (C4 plants) are less competitive than $\mathrm{C} 3$ weeds species under tree (Bayala et al., 2015). In addition, due to the reduction of cereal yield under tree, some farmers do not cultivate the area beneath tree as recommended by Saidou et al. (2012). These areas then constitute reserves of weed seeds. Therefore, growing a shade tolerant crop under tree could help controlling weeds in parkland agroforestry systems.

In the present study, the effects of microclimate due to tree presence on weeds development in millet (Pennisetum glaucum) and taro plots were assessed under Baobab (Adansonia digitata) and Néré (Parkia biglobosa) in a parkland with a view to identifying weeds species specific to the microclimate due to trees presence and to reduce the development of weeds by growing a shade tolerant crop (Colocasia esculenta) in the area shaded by tree crown.

\section{MATERIALS AND METHODS}

\section{Study site}

The study was carried out in a parkland in Nobéré, a village located at $11^{\circ} 30^{\prime}$ North and $00^{\circ} 58^{\prime}$ West in the south-central region of 
Burkina Faso (West Africa). The area is Sudanian savanna zone with a rainy season of 4-5 months and annual rainfall of 800-1000 $\mathrm{mm}$ (Nikiéma, 2005). The rainfall in 2007 was $46.1 \mathrm{~mm}$ higher than the normal maximum for the region. As showed on Figure 1, the high rainfall of 2007 was not evenly distributed and about half of the annual rainfall was recorded only in August (412 mm). The soil is luvisol with a sandy loam texture (clay $=11.5 \%$, silt $=$ $20.1 \%$ and sand $=68.4 \%$ ) with low nutrient content $\left(\mathrm{N}=0.69 \mathrm{~g} \mathrm{~kg}^{-1}, \mathrm{P}=0.14 \mathrm{~g} \mathrm{~kg}^{-1}\right.$ and $\mathrm{K}=0.50 \mathrm{~g} \mathrm{~kg}^{-1}$ ) and low organic matter content $(1.32 \%)$ in the 10 -cm upper soil layer (Sanou et al., 2012b).

The study was carried out in a parkland of 100 ha where the most frequent tree species were indigenous fruit trees including Adansonia digitata, Lannea microcarpa, Parkia biglobosa and Vitellaria paradoxa (Sanou et al., 2012b). Tree densities per species on the parkland were 0.25 individual $\mathrm{ha}^{-1}$ for $A$. digitata (Baobab), $1.18 \mathrm{ha}^{-1}$ for $L$. microcarpa, $1.81 \mathrm{ha}^{-1}$ for $P$. biglobosa (Néré) and $9.76 \mathrm{ha}^{-1}$ for $V$. paradoxa (Karité). The overall average tree density for all species was 13.58 individuals ha-1 (Sanou et al., 2012b).

\section{Tree selection}

The two tree species, Adansonia digitata and Parkia biglobosa were chosen for the study because of their high frequency in parklands of Sudanian savanna zone and also because of their contrasting phenology and light interception. Eight isolated mature trees of each of the two tree species (A. digitata and $P$. biglobosa) were randomly selected within a parkland. Tree characteristics such as height, circumference at $1.30 \mathrm{~m}$ aboveground and average crown (north-south and east-west orientations) diameters were measured and used to plan the experimental design. Average height, circumference at $1.30 \mathrm{~m}$ and crown diameter were $15.50 \pm 1.10 \mathrm{~m}, 5.92 \pm 0.59 \mathrm{~m}$ and $16.52 \pm 0.82 \mathrm{~m}$, respectively for baobab and $11.07 \pm 0.33 \mathrm{~m}, \quad 2.19 \pm 0.11 \mathrm{~m}$ and $17.14 \pm 0.83 \mathrm{~m}$, respectively for Néré.

\section{Experimental design and layout}

The area around each of the selected sixteen trees was subdivided into three concentric zones according to its crown size as follows:

Zone A - from the trunk of each tree up to half of the radius of the tree crown;

Zone B - from half of the radius of the tree crown up to the edge of the crown;

Zone $\mathrm{C}$ - from the edge of the tree crown up to $3 \mathrm{~m}$ away;

A control plot (Zone $\mathrm{H}$ ) of an area of 8 x $8 \mathrm{~m}$ was delimited for each sample tree to assess crops performance in the open area. The control plot was situated at least $40 \mathrm{~m}$ away from the edge of the crown of the sample tree but not shaded by any of the surrounding trees at any time of the day throughout the cropping season (Figure 2). Dividing the area under tree into concentric zones were preferred to directional transects to reduce directional biases related to leaf and rainfall, and micro-variability of soil fertility and to separate the different influence zones of tree as defined by Rao et al. (1998). In addition, these zones reflect different light interception by both trees as observed by Sanou et al. (2012a). The authors showed that the photosynthetically active radiation (PAR) recorded in the open area $\left(67.78 \mathrm{~mol} \mathrm{~m}^{-2}\right.$ per day) was reduced under $P$. biglobosa by $82.73 \%, 55.16 \%$ and $18.42 \%$ (in zones A, B and $\mathrm{C}$, respectively) while under $A$. digitata the reduction was $62.49 \%, 37.74 \%$ and $15.48 \%$ (in the zones A, B and C, respectively).

Taro was grown under four selected trees of each tree species and millet under the other four trees of each species. The association of crops to selected trees was randomly done for each tree species. At the time of crop sowing, two weeds plots (WP) of $0.5 \mathrm{mX} 0.5 \mathrm{~m}\left(0.25 \mathrm{~m}^{2}\right)$ were randomly located within each concentric zone and the control plot (Figure 2). These plots were not weeded throughout the growing season. The weeds on these plots were identified and harvested just before crop harvest. 


\section{Data assessment}

For each tree species and each crop, the number of species of weeds (Richness), the total number of individuals of each species (abundance) was determined for each zone (A, $\mathrm{B}$ and $\mathrm{C}$ ) and for the control plot. The relative frequency ( $\mathrm{F}$ in \%) of each weed species for each zone was calculated as:

\section{Number of individual s of a \\ $\mathrm{F}=100 \times \quad$ given species in the zone \\ Total number of individual $\mathrm{s}$ of all species in the zone}

The abundance of weed species in each zone was used to calculate Shannon's diversity index $(\mathrm{H})$ using the equation:

$\mathrm{H}=-\sum \frac{n}{N} \ln \left(\frac{n}{N}\right)$,

where $\mathrm{n}=$ number of individuals of a given species and $\mathrm{N}=$ total number of individuals of all species.

The total biomass of weeds per zone for each tree was weighed after drying the samples during 48 hours in an oven at $80^{\circ} \mathrm{C}$. Then, weeds were separated into different families and their species identified.

\section{Statistical analysis}

According to Wilson et al. (1998), it is not possible to calculate a valid estimation of error as residuals of zones are correlated in a concentric zones experimental design. Therefore, weeds parameters variations between concentric zones and the control plot were tested using a pairwise t-tests. It was assumed that the difference between the two zones compared was equal to zero and this hypothesis was rejected in case of a significant result of the t-test. An ANOVA using library Agricolae (1.2-1) of R software (3.2.1) was performed to test the effects of tree species and crops on Shannon's diversity index and weeds biomass production. The means were compared using Tukey's test at a confidence level of $95 \%$.

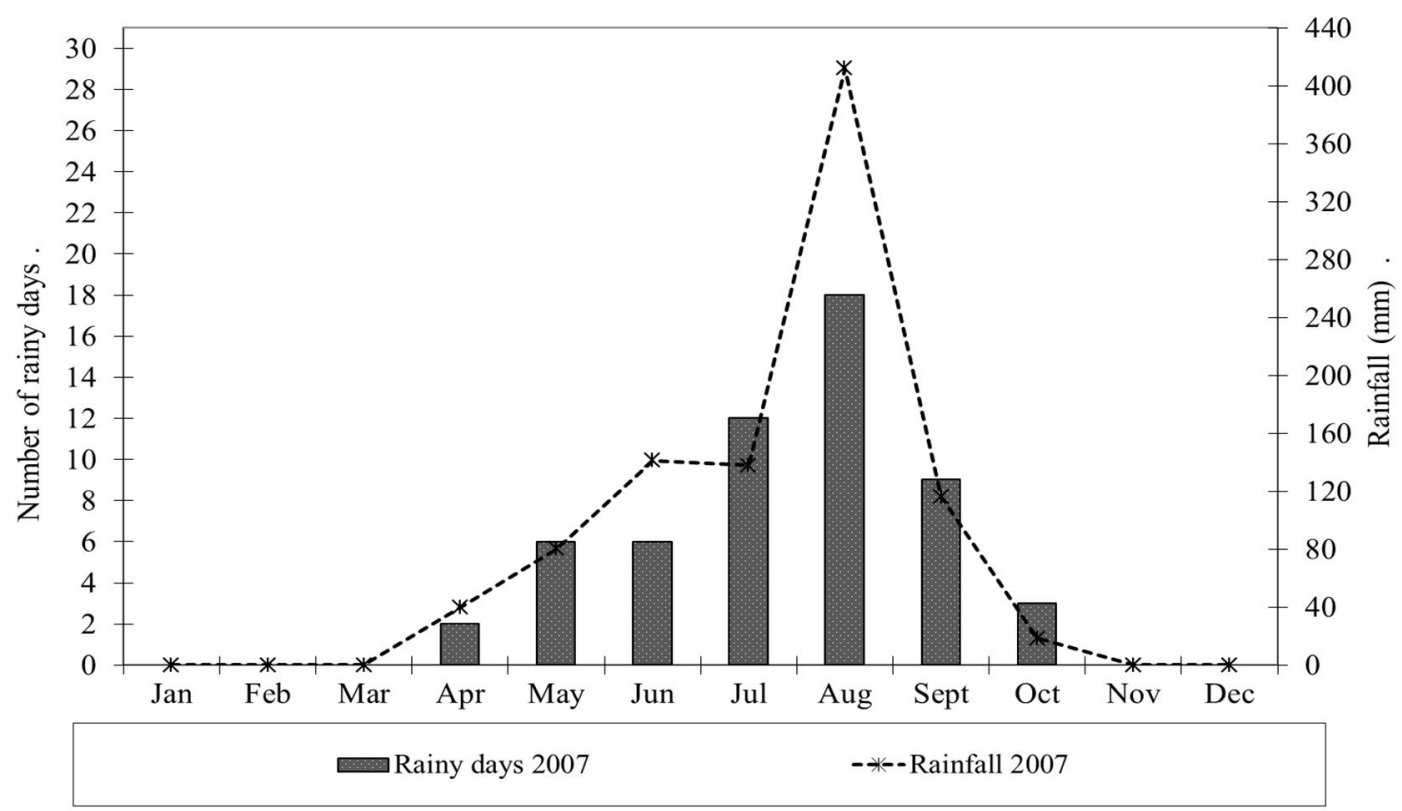

Figure 1: Rainfall pattern in 2007 in Nobéré (Burkina Faso). 




Figure 2: Experimental design with concentric zones (A, B, C) around a tree trunk and the control (H) with two weeds plots per zones. Zone A - from the trunk of each tree up to half of the radius of the tree crown; Zone B - from half of the radius of the tree crown up to the edge of the crown; Zone $\mathrm{C}$ - from the edge of the tree crown up to $3 \mathrm{~m}$ away; Zone $\mathrm{H}$ - Control plot

\section{RESULTS}

\section{Weed floristic composition}

Over the whole study area, 19 families of weed species were recorded but only 13 families were found in the open area, 12 families in the area influenced by baobab trees and 18 families under Néré trees. A total of 76 weed species were collected in the study area (Table 1) and, as shown in Table 2, 60\% of these species belong to the families of Poaceae, Fabaceae, Cyperaceae and Rubiaceae $(30 \%, \quad 12 \%, \quad 9 \%$ and $9 \%$ respectively).

Tree species had an impact on weed floristic composition (Table 3). The number of weed species found in the open area (32 species) was significantly lower $(\mathrm{P}=0.035)$ compared with the area under baobab and Néré trees (48 and 58 species, respectively). Seventeen (17) weed species were found under both tree species but were absent in the open area while six weed species were found only in the open area. Ten weed species were specific to the baobab and eighteen (18) were associated only with Néré trees (Table 4). For tree species and crop associations, the number of weed species was lower in both species associations with taro (29 and 40, for baobab 
and Néré, respectively), compared with their association with millet (39 and 41, for baobab and Néré, respectively). In the open area, taro plots also had lower number of weed species (17) compared with millet plots (25).

The weed floristic composition varied between concentric zones. The high representation of Poaceae, Cyperaceae, Fabaceae and Rubiaceae families in the open area decreased towards the trunks of both tree species. In the areas surrounding tree trunks, the most represented weed families were Amaranthaceae, Poaceae and Tiliaceae under baobab trees and Amaranthaceae, Lamiaceae, Poaceae and Acanthaceae under Néré trees. In the association between Néré trees and both crops, the number of weed species significantly $(\mathrm{P}=0.042)$ decreased from zone $\mathrm{C}$ (25 and 24, for millet and taro, respectively) to zone A (15 and 17, for millet and taro, respectively), while in the association of baobab trees and taro, weed species number increased from zone C (6) to zone A (16) (Table 3). For the association of baobab trees and millet, the highest number of weed species was recorded in zone B (23) and the lowest in zone A (17).

The most represented weed species in a plot changed with the crop species and zone (Tables 5 and 6). In the open area, the millet plots were more infested by Alysicarpus ovalifolius and Spermacoce radiata (11\%) while the major weeds in taro plots were Digitaria horizontalis and Fimbrystilis hyspidula (15\%). The most represented weed species in the zones under baobab trees crown (zones A and B) was Commelina forskaolaei (in association with millet $17 \%$ and $13 \%$, respectively and $14 \%$ and $21 \%$, respectively in association with taro). For baobab trees associated with taro, Leucas martinicensis
(14\%) had the same frequency as Commelina forskaolaei in zone A. Commelina forskaolaei and Leucas martinicensis were also the major weed species $(13 \%)$ in zone A of Néré trees associated with millet, while in zone B, Leucas martinicensis was the most represented weed (17\%). Zone A of the Néré and taro association was most occupied by Leucas martinicensis (11\%) and Pennisetum pedicellatum (11\%) whereas zone B was most infested by Tacca involucrata (13\%).

There was significant difference of Shannon's diversity index (SDI) between tree species (2.57 and 2.86, A: digitata and $P$. biglobosa, respectively) and between crops (2.86 and 2.60, millet and taro, respectively; $\mathrm{P}=0.026$ ). No significant interaction was noticed between the factors tree species and crops. As showed in Figure 3; there was a slightly increase of SDI from tree trunk to the open field for millet plots. In contrast, no significant difference was noticed in SDI of taro plot according to zones. In addition, SDI was lower in taro plots of zones B,C and $\mathrm{H}$ compared with millet plots.

\section{Weeds biomass}

There was no significant difference in the biomass production of weeds between tree species and between crops $(\mathrm{P}=0.071)$. The average weights of weeds harvested under baobab and Néré trees were $238.17 \pm 46 \mathrm{~g} \mathrm{~m}^{-2}$ and $221.75 \pm 60 \mathrm{~g} \mathrm{~m}^{-2}$, respectively. Weeds biomass productions were $225.44 \pm 41 \mathrm{~g} \mathrm{~m}^{-2}$ and $230.44 \pm 64 \mathrm{~g} \mathrm{~m}^{-2}$ in millet and taro plots, respectively.

The biomass production of weeds was similar in all zones for millet plots while lowest dry matter of weeds $\left(145.00 \pm 21 \mathrm{~g} \mathrm{~m}^{-2}\right)$ was recorded in zone A for taro plots (Figure $4)$. 
J. SANOU et al. / Int. J. Biol. Chem. Sci. 11(2): 623-639, 2017

Table 1: Families and species of weeds recorded in 2007 in the study site in Nobéré in Burkina Faso.

\begin{tabular}{|c|c|c|c|c|c|c|c|c|}
\hline $\mathbf{N}$ & Families & Weed species & $\mathbf{N}$ & Families & Weed species & $\mathbf{N}$ & Families & Weed species \\
\hline 1 & Acanthaceae & Dicliptera verticillata & 27 & Fabaceae & Alysicarpus vaginalis & 52 & Poaceae & Elionurus elegans \\
\hline 2 & Acanthaceae & Monechma ciliatum & 28 & Fabaceae & Cassia tora & 53 & Poaceae & Eragrostis ciliaris \\
\hline 3 & Acanthaceae & Peristrophe paniculata & 29 & Fabaceae & Crotalaria goreensis & 54 & Poaceae & Eragrostis pilosa \\
\hline 4 & Amaranthaceae & Achyrantes aspera & 30 & Fabaceae & crotalaria retusa & 55 & Poaceae & Eragrostis tremula \\
\hline 5 & Amaranthaceae & Alternantera nodiflora & 31 & Fabaceae & Indigofera dendrö̈des & 56 & Poaceae & Hackelochloa granularis \\
\hline 6 & Amaranthaceae & Amaranthus viridis & 32 & Fabaceae & Rhyconsia minima & 57 & Poaceae & Panicum leatum \\
\hline 7 & Amaranthaceae & Celosia trigyna & 33 & Fabaceae & Tephrosia pedicellata & 58 & Poaceae & Panicum maximum \\
\hline 8 & Araceae & Stylochaeton hypogaeus & 34 & Fabaceae & Vigna sp & 59 & Poaceae & Paspalum scrobiculatum \\
\hline 9 & Asteraceae & Ageratum conyzoïdes & 35 & Lagascae & Physalis micrantha & 60 & Poaceae & Pennisetum pedicellatum \\
\hline 10 & Asteraceae & Aspilia busei & 36 & Lamiaceae & Hyptis sipicigera & 61 & Poaceae & Pennisetum polystachion \\
\hline 11 & Asteraceae & Pentanema indicum & 37 & Lamiaceae & Leucas martinicensis & 62 & Poaceae & Schyrachyrium brevifolium \\
\hline 12 & Asteraceae & Vernonia galamensis & 38 & Lamiaceae & Ocimum americanum & 63 & Poaceae & Setaria pumila \\
\hline
\end{tabular}


J. SANOU et al. / Int. J. Biol. Chem. Sci. 11(2): 623-639, 2017

\begin{tabular}{|c|c|c|c|c|c|c|c|c|}
\hline 13 & Caryophylaceae & Polycarpaea corymbosa & 39 & Malvaceae & Sida acuta & 64 & Rubiaceae & Kohautia senegalensis \\
\hline 14 & Commelinaceae & Commelina benghalensis & 40 & Pedaliaceae & Ceratotheca sesamoïdes & 65 & Rubiaceae & Mitracarpus hirtus \\
\hline 15 & Commelinaceae & Commelina forskaolaei & 41 & Poaceae & Achelochloa granularis & 66 & Rubiaceae & Mytracarpus scaber \\
\hline 16 & Commelinaceae & Commelina sp & 42 & Poaceae & Acroceras amplectens & 67 & Rubiaceae & Oldelandia corymbosa \\
\hline 17 & Convolvulaceae & Evolvulus alsinoïdes & 43 & Poaceae & Andropogon gayanus & 68 & Rubiaceae & Oldelandia lantifolia \\
\hline 18 & Convolvulaceae & Ipomøe eriocarpa & 44 & Poaceae & Andropogon pseudapricus & 69 & Rubiaceae & Spermacoce radiata \\
\hline 19 & Cyperaceae & $\begin{array}{l}\text { Abildgaardia hispidula } \\
\text { subsp. senegalensis }\end{array}$ & 45 & Poaceae & Aristida funiculata & 70 & Rubiaceae & Spermacoce stachydea \\
\hline 20 & Cyperaceae & $\begin{array}{l}\text { Cyperus michelianus subs } \\
\text { pygmaeus }\end{array}$ & 46 & Poaceae & Brachiaria distichophylla & 71 & Scrophulariaceae & Striga hermonteca \\
\hline 21 & Cyperaceae & Cyperus sp & 47 & Poaceae & Brachiaria lata & 72 & Sphenocleaceae & Sphenochlea zeylanica \\
\hline 22 & Cyperaceae & Fimbristylis sp & 48 & Poaceae & Chasmopodium caudatum & 73 & Taccaceae & Tacca involucrata \\
\hline 23 & Cyperaceae & Fimbrystilis ferruginea & 49 & Poaceae & Dactyloctenium aegyptium & 74 & Tiliaceae & Corchorus fascicularis \\
\hline 24 & Cyperaceae & Fimbrystilis hyspidula & 50 & Poaceae & Digitaria horizontalis & 75 & Tiliaceae & corchorus tridens \\
\hline 25 & Cyperaceae & Mariscus sp & 51 & Poaceae & Digitaria perrottetii & 76 & Tiliaceae & Triumfetta rhomboidea \\
\hline 26 & Fabaceae & Alysicarpus ovalifolius & & & & & & \\
\hline
\end{tabular}


Table 2: Frequencies of weed species according to weed families recorded in 2007 in a parkland system in Nobéré in Burkina Faso.

\begin{tabular}{lc}
\hline Families & Frequency $\mathbf{( \% )}$ \\
\hline Poaceae & 30 \\
Fabaceae & 12 \\
Cyperaceae & 9 \\
Rubiaceae & 9 \\
Amaranthaceae & 5 \\
Asteraceae & 5 \\
Acanthaceae & 4 \\
Commelinaceae & 4 \\
Lamiaceae & $\mathbf{4}$ \\
Tiliaceae & $\mathbf{4}$ \\
Convolvulaceae & $\mathbf{3}$ \\
Araceae & $\mathbf{1}$ \\
Caryophylaceae & $\mathbf{1}$ \\
Lagascae & $\mathbf{1}$ \\
Malvaceae & $\mathbf{1}$ \\
Pedaliaceae & $\mathbf{1}$ \\
Scrophulariaceae & $\mathbf{1}$ \\
Sphenocleaceae & $\mathbf{1}$ \\
Taccaceae & $\mathbf{1}$ \\
\hline
\end{tabular}

Table 3: Number of weed species (Richness) recorded in millet (Pennisetum glaucum) and taro (Colocasia esculenta) associations with baobab (Adansonia digitata) and Néré (Parkia biglobosa) trees and the open field in a parkland system in Nobéré in Burkina Faso.

\begin{tabular}{|c|c|c|c|c|c|c|c|c|c|c|c|c|c|c|}
\hline \multirow{3}{*}{ Families } & \multicolumn{6}{|c|}{ Baobab } & \multicolumn{6}{|c|}{ Néré } & \multicolumn{2}{|c|}{ Open field } \\
\hline & \multicolumn{3}{|c|}{ Millet } & \multicolumn{3}{|c|}{ Taro } & \multicolumn{3}{|c|}{ Millet } & \multicolumn{3}{|c|}{ Taro } & \multirow{2}{*}{$\begin{array}{c}\text { Millet } \\
\mathbf{H} \\
\end{array}$} & \multirow{2}{*}{$\begin{array}{c}\text { Taro } \\
\mathbf{H}\end{array}$} \\
\hline & $\mathbf{A}$ & B & C & $\mathbf{A}$ & B & C & $\mathbf{A}$ & B & C & $\mathbf{A}$ & B & C & & \\
\hline Acanthaceae & 1 & & & 1 & 1 & 1 & 1 & 1 & & 2 & 1 & & & 1 \\
\hline Amaranthaceae & 2 & 3 & & 2 & 1 & & 3 & 2 & & & & & & \\
\hline Araceae & & & & & & & & & & & 1 & & & \\
\hline Asteraceae & 2 & 1 & & & & & & 1 & & 1 & & & & 1 \\
\hline Caryophylaceae & & & & & & & & & & & & 1 & 1 & \\
\hline Commelinaceae & 1 & 1 & & 2 & 1 & & 1 & 1 & & 2 & & 1 & & 1 \\
\hline Convolvulaceae & & 1 & 1 & & 1 & & & & & & 1 & 1 & 1 & \\
\hline Cyperaceae & 1 & 1 & 1 & 3 & 1 & 1 & & & 3 & & 1 & 3 & 4 & 2 \\
\hline
\end{tabular}




\begin{tabular}{|c|c|c|c|c|c|c|c|c|c|c|c|c|c|c|}
\hline Fabaceae & 1 & 2 & 4 & & 1 & 1 & & 1 & 4 & & 1 & 2 & 1 & 1 \\
\hline Lagascae & & & & & & & 1 & 1 & & 1 & & & & \\
\hline Lamiaceae & 1 & 3 & 1 & 1 & 1 & & 2 & 2 & 2 & 2 & 2 & 1 & 1 & 1 \\
\hline Malvaceae & & & & & & & & & 1 & & & & & \\
\hline Pedaliaceae & & & & & & & & & & & & & 1 & \\
\hline Poaceae & 4 & 8 & 7 & 6 & 5 & 1 & 6 & 5 & 6 & 6 & 7 & 9 & 9 & 4 \\
\hline Rubiaceae & 1 & 1 & 4 & & 1 & 1 & & & 6 & 1 & 2 & 4 & 5 & 4 \\
\hline Scrophulariaceae & & & 1 & & & & & & & & & 1 & 1 & 1 \\
\hline Sphenocleaceae & & & & & & & & 1 & & & & & & \\
\hline Taccaceae & & & & & & & & & & 1 & 1 & & & \\
\hline Tiliaceae & 3 & 2 & & 1 & & 1 & 1 & 3 & 3 & 1 & 1 & 1 & 1 & 1 \\
\hline Richness (Zone) & 17 & 23 & 19 & 16 & 13 & 6 & 15 & 18 & 25 & 17 & 18 & 24 & 25 & 17 \\
\hline Richness (Crop) & & 39 & & & 29 & & & 41 & & & 40 & & 25 & 17 \\
\hline $\begin{array}{l}\text { Richness (Tree } \\
\text { species) }\end{array}$ & & & 48 & & & & & & 5 & & & & & \\
\hline
\end{tabular}

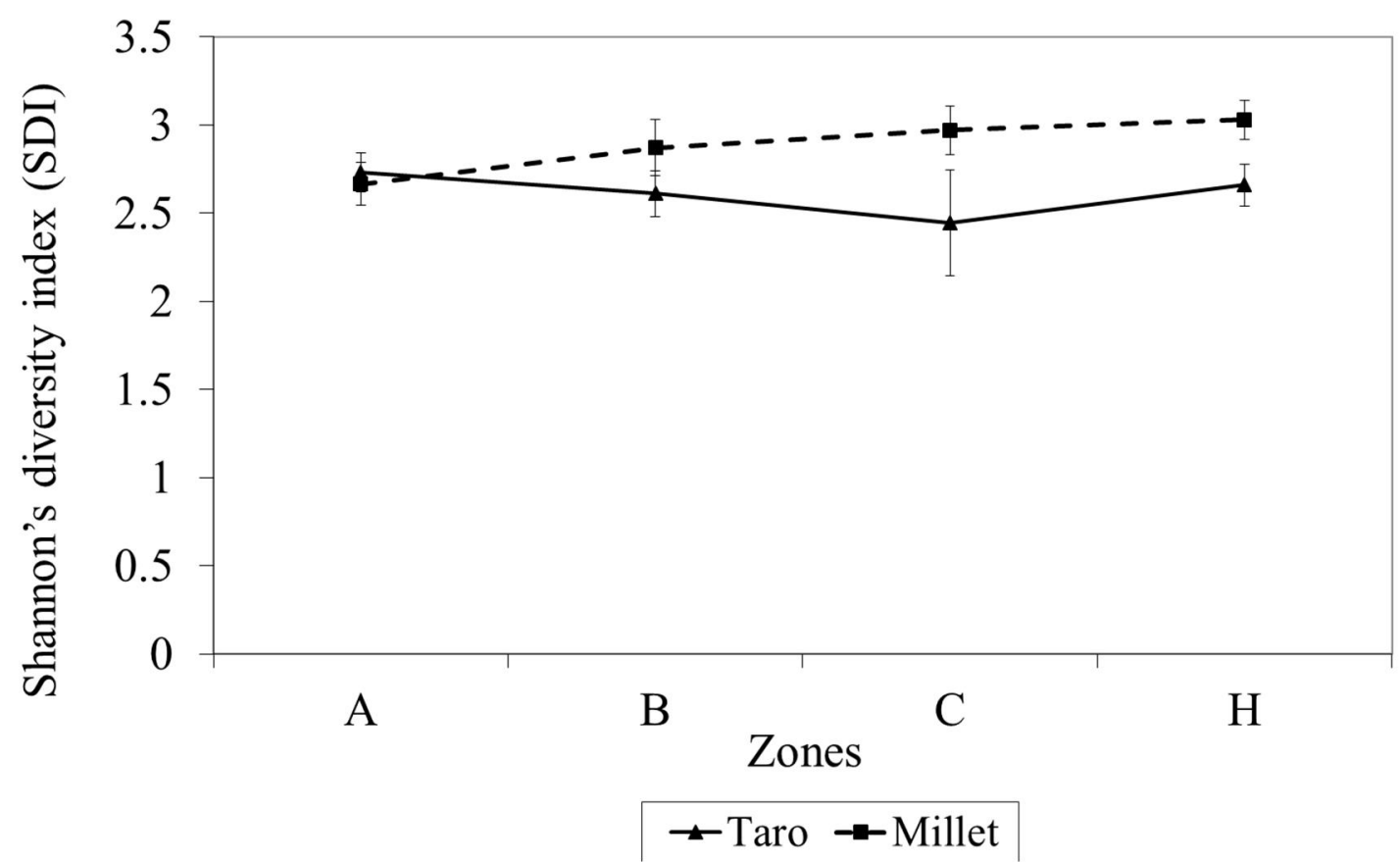

Figure 3: Shannon's diversity index in millet and taro plots according to zones influenced by trees $(\mathrm{A}, \mathrm{B}, \mathrm{C})$ and in the open field $(\mathrm{H})$ in a parkland system in Nobéré in Burkina Faso. 
Table 4: Weed species specific to the open field and to the areas under the influence of baobab (Adansonia digitata) and Néré (Parkia biglobosa) trees recorded in 2007 in a parkland system in Nobéré in Burkina Faso.

\begin{tabular}{|c|c|c|c|c|}
\hline $\mathrm{N}$ & $\begin{array}{l}\text { Weeds specific to both } \\
\text { trees species }\end{array}$ & $\begin{array}{l}\text { Weeds specific to } \\
\text { baobab trees }\end{array}$ & $\begin{array}{c}\text { Weeds specific to Néré } \\
\text { trees }\end{array}$ & $\begin{array}{l}\text { Weeds specific to } \\
\text { the open area }\end{array}$ \\
\hline 1 & Achyrantes aspera & $\begin{array}{c}\text { Achelochloa } \\
\text { granularis }\end{array}$ & $\begin{array}{c}\text { Abildgaardia hispidula } \\
\text { senegalensis }\end{array}$ & $\begin{array}{c}\text { Andropogon } \\
\text { pseudapricus }\end{array}$ \\
\hline 2 & Acroceras amplectens & $\begin{array}{l}\text { Ageratum } \\
\text { conyzoïdes }\end{array}$ & Alternantera nodiflora & $\begin{array}{l}\text { Ceratotheca } \\
\text { sesamoïdes }\end{array}$ \\
\hline 3 & Andropogon gayanus & Amaranthus viridis & 4lysicarpus vaginalis & $\begin{array}{l}\text { Dactyloctenium } \\
\text { aegyptium }\end{array}$ \\
\hline 4 & Aristida funiculata & Commelina $s p$ & Cassia tora & Elionurus elegans \\
\hline 5 & Brachiaria distichophvlla & Crotalaria ooreensis & $\begin{array}{l}\text { Commelina } \\
\text { benohalensis }\end{array}$ & Erarostis pilosa \\
\hline 6 & Brachiaria lata & Digitaria perrottetii & $\begin{array}{c}\text { Cyperus michelianus sb } \\
\text { pygmaeus }\end{array}$ & $\begin{array}{l}\text { Fimbrystilis } \\
\text { ferruginea }\end{array}$ \\
\hline 7 & Celosia trigyna & Mariscus sp & Eragrostis tremula & \\
\hline 8 & Corchorus fascicularis & $\begin{array}{c}\text { Ocimum } \\
\text { americanum }\end{array}$ & Evolvulus alsinoïdes & \\
\hline 9 & Dicliptera verticillata & Vernonia galamensis & Fimbristylis $s p$ & \\
\hline 10 & Eragrostis ciliaris & Vigna $s p$ & Indigofera dendrö̈des & \\
\hline 11 & Hyptis sipicigera & & Oldelandia lantifolia & \\
\hline 12 & Panicum leatum & & Pentanema indicum & \\
\hline 13 & Paspalum scrobiculatum & & Physalis micrantha & \\
\hline 14 & Pennisetum polystachion & & Rhyconsia minima & \\
\hline 15 & Peristrophe paniculata & & Sida acuta & \\
\hline 16 & Tephrosia pedicellata & & Sphenochlea zeylanica & \\
\hline 17 & Triumfetta rhomboidea & & Stylochaeton hypogaeus & \\
\hline 18 & & & Tacca involucrata & \\
\hline
\end{tabular}


Table 5: Ranking of weed species with relative frequencies (F) $\geq 5 \%$ in millet (Pennisetum glaucum) and taro (Colocasia esculenta) plots located in zones under tree influence of a parkland in Nobéré in Burkina Faso (2007).

\begin{tabular}{|c|c|c|c|c|c|c|}
\hline \multirow[t]{2}{*}{ Crops } & \multicolumn{2}{|l|}{ Zone A } & \multicolumn{2}{|l|}{ Zone B } & \multicolumn{2}{|l|}{ Zone C } \\
\hline & Weeds species & F (\%) & Weeds species & F (\%) & Weeds species & F (\%) \\
\hline \multirow[t]{6}{*}{ Millet } & Commelina forskaolaei & 15 & Commelina forskaolaei & 11 & Digitaria horizontalis & 10 \\
\hline & Leucas martinicensis & 11 & Leucas martinicensis & 11 & Alysicarpus ovalifolius & 8 \\
\hline & Achyrates aspera & 9 & Digitaria horizontalis & 8 & Spermacoce radiata & 8 \\
\hline & Corchorus tridens & 9 & Corchorus tridens & 7 & Pennisetum pedicellatum & 7 \\
\hline & Pennisetum pedicellatum & 6 & Alysicarpus ovalifolius & 5 & Leucas martinicensis & 5 \\
\hline & & & Pennisetum polystachion & 5 & & \\
\hline \multirow[t]{14}{*}{ Taro } & Leucas martinicensis & 13 & Commelina forskaolaei & 9 & Spermacoce radiata & 11 \\
\hline & Commelina forskaolaei & 10 & Leucas martinicensis & 9 & Corchorus fascicularis & 5 \\
\hline & Celosia trigyna & 5 & Pennisetum pedicellatum & 7 & Cyperus sp & 5 \\
\hline & Eragrostis ciliaris & 5 & Tacca involucrata & 7 & Fimbrystilis hyspidula & 5 \\
\hline & Pennisetum pedicellatum & 5 & Digitaria horizontalis & 5 & Mitracarpus hirtus & 5 \\
\hline & Pennisetum polystachion & 5 & Hackelochloa granularis & 5 & Panicum maximum & 5 \\
\hline & Triumfetta rhomboidea & 5 & Hyptis sipicigera & 5 & Pennisetum pedicellatum & 5 \\
\hline & & & Ipomøa eriocarpa & 5 & Pennisetum polystachion & 5 \\
\hline & & & Panicum leatum & 5 & Polycarpaea corymbosa & 5 \\
\hline & & & Panicum maximum & 5 & & \\
\hline & & & Pennisetum polystachion & 5 & & \\
\hline & & & Peristrophe paniculata & 5 & & \\
\hline & & & Setaria pumila & 5 & & \\
\hline & & & Spermacoce stachydea & 5 & & \\
\hline
\end{tabular}


Table 6: Ranking of weed species with relative frequencies (F) $\geq 5 \%$ in millet (Pennisetum glaucum) and taro (Colocasia esculenta) plots located in the open field of a parkland in Nobéré in Burkina Faso (2007).

\begin{tabular}{lllr}
\hline \multicolumn{1}{c}{ Millet } & \multicolumn{2}{c}{ Taro } \\
\hline Weeds species & \multicolumn{1}{l}{ F } & & \\
\hline Alysicarpus ovalifolius & 10.87 & Deeds species & Digitaria horizontalis \\
Spermacoce radiata & 10.87 & Fimbrystilis hyspidula & 14.81 \\
Cyperus sp & 6.52 & Commelina forskaolaei & 14.81 \\
Digitaria horizontalis & 6.52 & corchorus tridens & 11.11 \\
Ipomoea eriocarpa & 6.52 & Leucas martinicensis & 7.41 \\
Oldelandia corymbosa & 6.52 & 7.41 \\
Spermacoce stachydea & 6.52 & \\
\hline
\end{tabular}

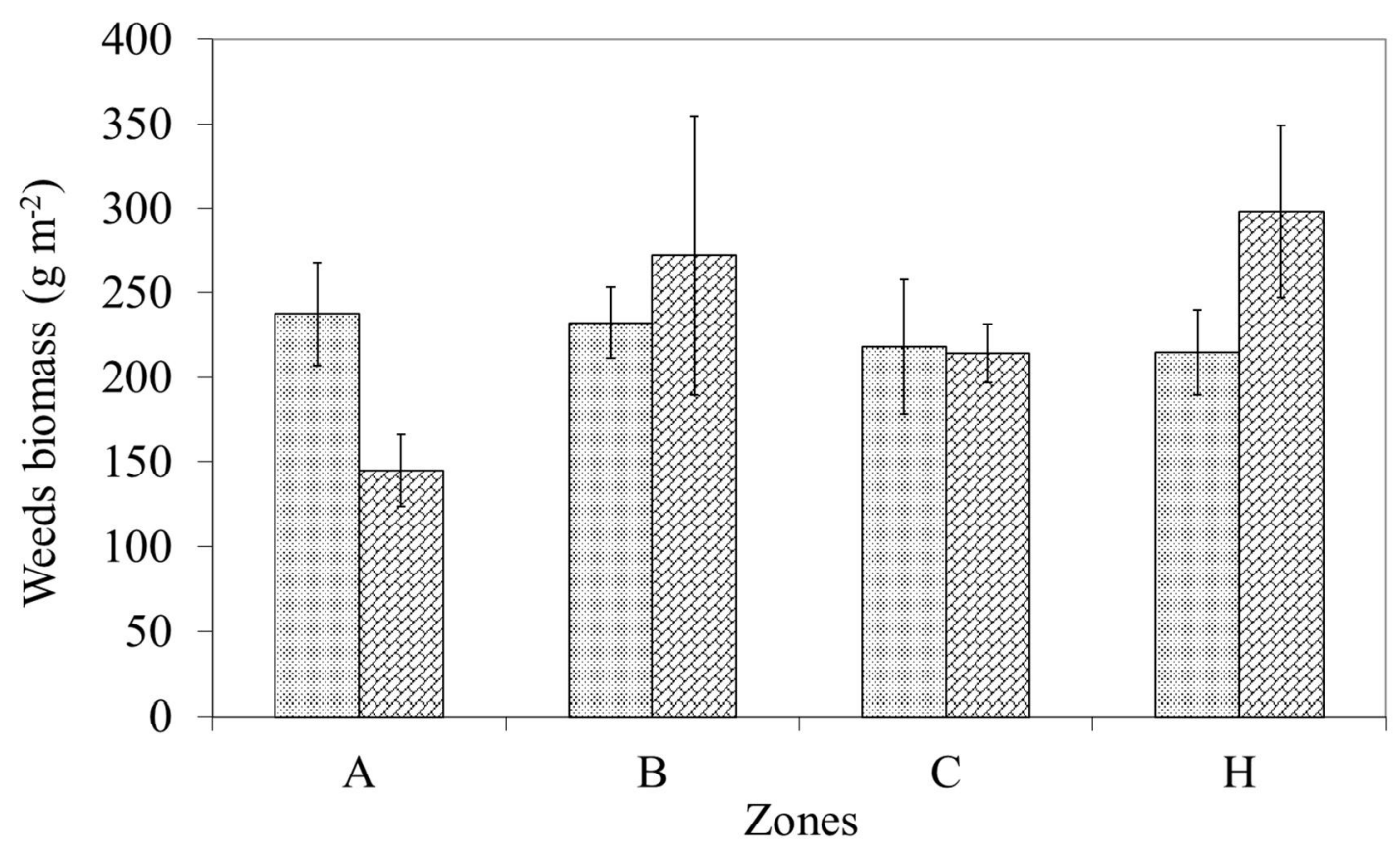

圈 Millet 图Taro

Figure 4: Biomass production of weeds $\left(\mathrm{g} \mathrm{m}^{-2}\right)$ in millet and taro plots according to zones influenced by trees (A, B, C) and in the open field $(\mathrm{H})$ in a parkland system in Nobéré in Burkina Faso. 


\section{DISCUSSION}

The main frequent weed families in the studied parkland were Poaceae, Fabaceae, Cyperaceae and Rubiaceae. These are the dominant families of weeds flora in West Africa as reported by Chikoye and Ekeleme (2001). These authors classified the dominant weeds families as Poaceae with 47 genera, Asteraceae with 23 genera, Papilionaceae with 15 genera, Euphorbiaceae with 11 genera, Rubiaceae with 11 genera and Cyperaceae with 10 genera.

One of the effects of trees was an increase of the numbers of weed families and species in the present study, in contrast to previous works carried out on the effect of Faidherbia albida (Gworgwor, 2007) but in accordance with the change in weeds floristic composition due to tree effects in pasture lands noticed by Kambatuku et al. (2011) and Ludwig et al. (2004) (1998). Weed floristic composition also varied between tree species in accordance with the suggestion of Boffa (1999): Photosynthetically active radiation (PAR) reduction under trees as reported by Sanou et al. (2012a), suppresses non-shade tolerant species. Weeds were more diversified under $P$. biglobosa compared with $A$. digitata according to Shannon's diversity index.

According to zones, the number of weed species increased from the tree trunk to the surrounding area of the edge of tree crown for the association of Néré trees with both crops. In contrast, weed species number decreased from the tree trunk to the surrounding area of the edge of tree crown in baobab associated with taro. No trend was observed for weed species number in baobab and millet association. As suggested by Boffa (1999), the distribution of weed species number according to the zones seems to be related to PAR availability. Indeed, a lower number of weed species was noted in the area under Néré trees crowns where PAR was more reduced (Sanou et al., 2012a), compared to the shaded area of baobab trees and the open area. In addition, weed species number was reduced in taro plots compared with millet plots due to the higher leaf area of taro plants. However, as suggested by Ludwig et al. (2004), weed species number could be increased by the favourable conditions (higher water and nutrient contents of soil, lower temperature) in zones influenced by trees where PAR reduction was low (B and $\mathrm{C}$ for baobab and $\mathrm{C}$ of Néré) as reported by Sanou et al.(2012a). Finally, the higher number of weed species under tree crowns could be related to seed dispersion of weeds by wind, birds and animals as observed by previous workers (Milton and Dean, 2001). It could be also resulting from of weed seeds carried by wind that are trapped by tree canopy.

Shannon's diversity index showed that growing taro reduced weeds species compared to millet. This result reflected the selection effect of taro leaves shade on under grown weeds. Indeed, taro plants were less tall compared with millet plants, had a larger leaf area (Sanou et al., 2012b) and then had a heaviest shade effect. Therefore, it is possible that most of the non-shade-tolerant weeds species were eliminated from taro plots reducing species diversity compared with millet plots. That is in accordance with the control effect of taro on weeds reported in 
previous works as its leaves generally cover the ground and shade out weeds (Mabhaudhi and Modi, 2014).

The dry matter production of weeds did not vary according to tree species. Weed biomass was higher in millet plots compared with taro plots in shaded zones (A), while in the open field higher biomass of weeds was recorded in taro plots compared with millet plots. So, the combination of shade effects and the growth of taro plants seemed to reduce weed dry matter production of weeds in the tree crown area. The reduction of weed dry matter production in taro plots of shaded zones could be explained by the greater shade effect of taro plots leaves compared with millet as indicated above and reported in previous works (Mabhaudhi and Modi, 2014). Therefore, the competition for light between crops and weeds in shaded areas was favourable to taro and the reverse was noticed in the full sun area.

\section{Conclusion}

The first hypothesis of the present study which was that the microclimate due to trees presence increases weeds species number in parklands has been confirmed by the results. Indeed, the weeds floristic composition was more diversified in area beneath trees and weeds species were different between baobab tree with less shade effect and Néré tree having more light reduction under its crown. It was also noted that the number of weeds species increased from Néré tree trunk to the open field in contrast of baobab tree associated with taro.
The results have also confirmed that the development of weeds is reduced when growing a shade tolerant crop (taro) compared with shade intolerant cereal (Millet) in tree beneath, which was the second hypothesis of the study. In addition, growing taro reduced the number of weeds species and also weeds development (low biomass production) under tree crown. Therefore, introducing a shade tolerant crop as taro in parkland agroforestry system could help farmers controlling weeds in their farms.

\section{COMPETING INTERESTS}

There are no competing interests for this article.

\section{AUTHORS' CONTRIBUTIONS}

JS designed the experiment and gathered the data. HRB and MCED helped in analysis and write up. JB supervised the design, the entire data collection process and provided guide, corrections and supervision to the entire research and critically read and amended the manuscript. All the authors read and approved the final manuscript.

\section{ACKNOWLEDGEMENTS}

This study was funded by the project SAFRUIT/ INCO Contract Number 015465 of the European Commission. Issouf Ouattara is acknowledged for field assistance. We wish to thank the farmers in Nobéré for their permission and participation in the field experiment. 


\section{REFERENCES}

Bayala J, Sanou J, Teklehaimanot Z, Sinclair F. 2015. Adaptation of crops to partial shade in mixed cropping systems. In Tree-crop Interactions: Agroforestry in a Changing Climate, Ong CK B, Black C, Wilson J (eds). CABI: Wallingford, UK, 309-325.

Bayala J, Sanou J, Teklehaimanot Z, Kalinganire A, Ouedraogo SJ, 2014. Parklands for buffering climate risk and sustaining agricultural production in the Sahel of West Africa, Current Opinion in Environmental Sustainability, 6: 28-34. DOI: http://dx.doi.org/10.1016/ j.cosust.2013.10.004

Bayala J, Teklehaimanot Z, Ouedraogo SJ, 2002. Millet production under pruned tree crowns in a parkland system in Burkina Faso. Agroforestry Systems, 54: 203-214. DOI: 10.1023/A: 1016058906682

Bellow JG, Nair PK. 2003. Comparing common methods for assessing understory light availability in shadedperennial agroforestry systems. Agricultural and Forest Meteorology, 114: 197-211. DOI: 10.1016/s01681923(02)00173-9

Boffa, JM. 1999. Agroforestry Parklands in Sub-Saharan Africa. FAO Conservation Guide 34. FAO: Rome, Italy, 230 p.

Chikoye D, Ekeleme F. 2001. Growth attributes of ten Mucuna accessions and their effect on speargrass (Imperata cylindrica) dry matter. Biol. Agric. Hortic, 18: 191-201. DOI: http://dx.doi.org/10.1080/01448765.2001 .9754883

Gworgwor NA. 2007. Trees to control weeds in pearl millet. Agron. Sustain. Dev., 27: 89-94. DOI: 10.1051/agro:2006028

Kambatuku JR, Cramer MD, Ward D. 2011. Savanna tree-grass competition is modified by substrate type and herbivory. Journal of Vegetation Science, 22: 225-237.DOI: 10.1111/j.1654-1103.2010.01239.x

Larwanou M, Yemshaw Y. Saadou M. 2010. Prediction models for estimating foliar and fruit dry biomasses of five Savannah tree species in the West African Sahel. Int. J. Biol. Chem. Sci., 4(6): 2245-2256. DOI: http://dx.doi.org/10.4314/ijbcs. v9i4. 12

Ludwig F, de Kroon H, Berendse F, Prins HHT. 2004. The influence of savanna trees on nutrient, water and light availability and the understorey vegetation. Plant Ecology, 170: 93-105. DOI: 10.1023/B:VEGE.0000019023. 29636.92

Mabhaudhi T, Modi AT. 2014. Intercropping Taro and Bambara Groundnut. In Sustainable Agriculture Reviews (Vol. 13). Lichtfouse, E (ed). Springer International Publishing: Cham, Vietnam; 275-290. DOI: 10.1007/978-3319-00915-5_9

Milton SJ, Dean WR. 2001. Seed dispersed in dung of insectivores and herbivores in semi-arid southern Africa. Journal of Arid Environments, 47: 465-483. DOI: 10.1006/jare.2000.0727 
Moustakas A, Kunin WE, Cameron TC, Sankaran M. 2013. Facilitation or Competition? Tree Effects on Grass Biomass across a Precipitation Gradient. PLoS ONE 8(2): e57025. doi:10.1371/journal.pone.0057025

Ndiaye Samba A, Elhadji F, Talla G, Hank M, Camiré C. 2012. Cordyla pinnata améliore les propriétés du sol et la productivité des cultures. Int. J. Biol. Chem. Sci., 6(2): 714-725. DOI: http://dx.doi.org/10.4314/ijbcs.v6i2.15

Noordwijk (Van) M, Lusiana B, Khasanah N. 2004. WaNuLCAS version 3.1, Background on a Model of Water, Nutrient and Light Capture in Agroforestry Systems. Bogor. International Centre for Research in Agroforestry (ICRAF); 246.

Sanou J, Bayala J, Bazié P, Teklehaimanot Z 2012a. Photosynthesis and biomass production by millet (Pennisetum glaucum) and taro (Colocasia esculenta) grown under baobab (Adansonia digitata) and Néré (Parkia biglobosa) in an agroforestry parkland system of Burkina Faso (West Africa). Expl Agric., 48(2): 283-300. DOI: https://doi.org/10.1017/S0014479712000 014

Sanou J, Bayala J, Teklehaimanot Z, Bazié P. 2012b. Effect of shading by baobab
(Adansonia digitata) and nere (Parkia biglobosa) on yields of millet (Pennisetum glaucum) and taro (Colocasia esculenta) in parkland systems in Burkina Faso, West Africa. Agroforest Syst., 85: 431-441. DOI : 10.1007/s10457-011-9405-4

Saïdou A, Balogoun I, Koné B, Gnanglé CP, Aho N. 2012. Effet d'un système agroforestier à karité (Vitellaria paradoxa c.f. gaertn) sur le sol et le potentiel de production du maïs (Zea maize) en zone Soudanienne du Bénin. Int. J. Biol. Chem. Sci., 6(5): 2066-2082. DOI :

http://dx.doi.org/10.4314/ijbcs.v6i5.16

Wilson TD, Brook RM, Tomlinson HF. 1998. Interaction between Néré (Parkia biglobosa) and under-planted sorghum in parkland systems in Burkina Faso. Experimental Agriculture, 35: 85-98. DOI: https://doi.org/10.1017/ S0014479798001069

Yameogo G, Yelemou B, Boussim IJ, Traore D, 2013. Gestion du parc agroforestier du terroir de Vipalogo (Burkina Faso) : contribution des ligneux à la satisfaction des besoins des populations. Int. J. Biol. Chem. Sci., 7(3): 1087-1105. DOI: http://dx.doi.org/10.4314/ijbcs.v7i3 